(C) 2022, The Authors. Published by Elsevier Inc. and Fass Inc. on behalf of the American Dairy Science Association ${ }^{\circledR}$. This is an open access article under the CC BY license (http://creativecommons.org/licenses/by/4.0/).

\title{
Phosphorylation and glycosylation isoforms of bovine K-casein variant $E$ in homozygous Swedish Red cow milk detected by liquid chromatography-electrospray ionization mass spectrometry
}

\author{
Bulei Sheng, ${ }^{1 *} \odot$ Martin N. Thesbjerg, ${ }^{1}$ Maria Glantz, ${ }^{2}$ Marie Paulsson, ${ }^{2}$ Søren D. Nielsen, ${ }^{1} \odot$ \\ Nina A. Poulsen, ${ }^{1}{ }^{\circ}$ and Lotte B. Larsen ${ }^{1}$ () \\ ${ }^{1}$ Department of Food Science, Aarhus University, Agro Food Park 48, 8200 Aarhus N, Denmark \\ 2Department of Food Technology, Engineering and Nutrition, Lund University, PO Box 124, SE-221 00, Lund, Sweden
}

\begin{abstract}
Variations in the phosphorylation and glycosylation patterns of the common $\kappa$-casein $(\mathrm{CN})$ variants $\mathrm{A}$ and $\mathrm{B}$ have been explored, whereas studies on variant $\mathrm{E}$ heterogeneity are scarce. This study reports for the first time the detailed phosphorylation and glycosylation pattern of the $\kappa-\mathrm{CN}$ variant $\mathrm{E}$ in comparison with variants A and B. Individual cow milk samples representing $\kappa$-CN genotype EE $(n=12)$ were obtained from Swedish Red cows, and the natural posttranslational modifications of its $\kappa-\mathrm{CN}$ were identified and quantified by liquid chromatography-electrospray mass spectrometry. In total, 12 unique isoform masses of $\kappa$ - $\mathrm{CN}$ variant $\mathrm{E}$ were identified. In comparison, $\mathrm{AA}$ and $\mathrm{BB}$ milk consisted of 14 and 17 unique isoform masses, respectively. The most abundant $\kappa-\mathrm{CN}$ E isoform detected in the EE milk was the monophosphorylated, unglycosylated [1P 0G, 70\%; where P indicates phosphorylation from single to triple phosphorylation (1-3P), and G indicates glycosylation from single to triple glycosylation (1-3G)] form, followed by diphosphorylated, unglycosylated (2P 0G, $\sim 12 \%)$ form, resembling known patterns from variants $\mathrm{A}$ and $\mathrm{B}$. However, a clear distinction was the presence of the rare triphosphorylated, nonglycosylated (3P 0G, $\sim 0.05 \%) \kappa-C N$ isoform in the EE milk. All isoforms detected in variant $\mathrm{E}$ were phosphorylated, giving a phosphorylation degree of $100 \%$. This is comparable with the phosphorylation degree of variants $\mathrm{A}$ and $\mathrm{B}$, being also almost $100 \%$, though with very small amounts of nonphosphorylated, glycosylated isoforms detected. The glycosylation degree of variant $\mathrm{E}$ was found to be around 17\%, a bit higher than observed for variant B (around 14\%), and higher than variant
\end{abstract}

Received August 18, 2021.

Accepted November 15, 2021.

*Corresponding author: bulei@food.au.dk
A (around 7\%). Among glycosylation, the glycan e was the most common type identified for all 3 variants, followed by c/d (straight and branched chain trisaccharides, respectively), and $\mathrm{b}$. In contrast to $\kappa$ - $\mathrm{CN}$ variants $\mathrm{A}$ and $\mathrm{B}$, no glycan of type a was found in variant $\mathrm{E}$. Taken together, this study shows that the posttranslational modification pattern of variant $E$ resembles that of known variants to a large extent, but with subtle differences.

Key words: posttranslational modifications, isoforms, glycan type, genetic variants

\section{INTRODUCTION}

$\kappa$-Casein is essential for structure, size, and stability of casein micelles in milk (Bijl et al., 2014). Properties of $k$-CN can be influenced by many factors, including genetic polymorphisms, which can lead to AA changes in the expressed proteins. Bovine $\kappa-\mathrm{CN}$ has been found to be present in at least 14 allelic variants, including $\mathrm{A}$, $\mathrm{A}^{\mathrm{I}}, \mathrm{B}, \mathrm{B}^{2}, \mathrm{C}, \mathrm{D}, \mathrm{E}, \mathrm{F}^{1}, \mathrm{~F}^{2}, \mathrm{G}^{1}, \mathrm{G}^{2}, \mathrm{H}, \mathrm{I}$, and J (Caroli et al., 2009). Among these genetic variants, A (reference variant) and $\mathrm{B}$ are the most common, whereas variant E has been identified especially in some Nordic cattle breeds, though in low frequencies, $<5 \%$ (Lien et al., 1999). Different genetic variants of $\kappa-\mathrm{CN}$ could lead to different processing properties and functionalities of milk (e.g., micelle size and coagulation properties). Variant B of $\kappa-\mathrm{CN}$ has been associated with smaller casein micelles and a higher relative concentration of glycosylated $\kappa-\mathrm{CN}$, compared with $\kappa-\mathrm{CN}$ variant A (Bijl et al., 2014; Sheng et al., 2021). Furthermore, improved coagulation properties have been associated with $\kappa-\mathrm{CN}$ variant B (Poulsen et al., 2013). $\kappa$-Casein variant E has previously been associated with poor or even noncoagulation properties in Swedish Red (Wedholm et al., 2006; Hallén et al., 2007) and Finnish Ayrshire (Ikonen et al., 1999) cattle. Poulsen et al. (2017a) also found a higher frequency of the $\kappa-\mathrm{CN} \mathrm{AE}$ haplotype in poorly coagu- 
lating milk compared with good coagulating milk from Danish Holstein, which probably correlated with casein micelle size. Smaller casein micelles have been shown to promote the coagulation process of milk (Glantz et al., 2010). These differences could, at least in part, relate to posttranslational modification (PTM) patterns of -CN by influencing casein micelle properties (Bijl et al., 2019), and eventually also its cleavage by chymosin (Jensen et al., 2015). However, studies on the topic of the PTM pattern of $\kappa-\mathrm{CN}$ variant $\mathrm{E}$ are limited.

The structural background for the $\mathrm{E}$ variant is that it has a substitution of $\mathrm{Ser}^{176}$ to Gly ${ }^{176}$ compared with both variants A and B (Caroli et al., 2009). It is important to note that the Ser ${ }^{176}$ is not in a position normally known to be part of PTM sites (Le et al., 2017). The phosphorylation sites of $\kappa$-CN primarily occur at Ser ${ }^{170}$ and subsequently at Ser ${ }^{148}$ (Talbot and Waugh, 1970; Mercier et al., 1973), but $\mathrm{Thr}^{166}$ and $\mathrm{Ser}^{187}$ can also be phosphorylated (Holland et al., 2006; HernándezHernández et al., 2011). Further distinctions between the variants are the presence of the polar residues $\mathrm{Thr}^{157}$ and $\mathrm{Asp}^{169}$ in variants $\mathrm{A}$ and $\mathrm{E}$, which in variant $\mathrm{B}$ are substituted by the more hydrophobic $\mathrm{Ile}^{157}$ and Ala ${ }^{169}$ residues.

Further PTM of $\kappa$-CN include O-linked glycosylation at some specific Thr residues. The attached glycans consist of galactose (Gal), $N$-acetylgalactosamine (GalNAc), and $\mathrm{N}$-acetylneuraminic (sialic) acid (NeuNAc). The most common type is tetrasaccharide (type e, $\sim 56 \%$ ), followed by trisaccharides with straight (type c, $\sim 18 \%$ ) or branched chain (type d, $\sim 18 \%$ ), disaccharide (type b, $\sim 6 \%$ ), and monosaccharide (type a, $\sim 1 \%$; Saito and Itoh, 1992). Six positions in variants $\mathrm{A}$ and $\mathrm{B}$ have been reported for glycosylation, consisting of $\mathrm{Thr}^{142}$, Thr ${ }^{152}$, $\mathrm{Thr}^{154}$, Thr ${ }^{163}$, $\mathrm{Thr}^{166}$ (could also be phosphorylated), and $\mathrm{Thr}^{186}$. In addition, the $\mathrm{Thr}^{157}$ present in variant $\mathrm{A}$ has also been identified as a potential glycosylation site (Pisano et al., 1994; Holland et al., 2005; Holland et al., 2006). Threonine ${ }^{157}$ is also present in variant $\mathrm{E}$, but the glycosylation of all these sites in variant $\mathrm{E}$ is not known. In spite of this additional potential position for glycosylation in both $\mathrm{A}$ and $\mathrm{E}, \kappa-\mathrm{CN}$ variant $\mathrm{A}$ has been shown to have a lower glycosylation degree, calculated as amount of glycosylated $\kappa-\mathrm{CN}$ isoforms relative to total $\kappa-\mathrm{CN}$, compared with B (Bijl et al., 2014; Sheng et al., 2021). The glycosylation degree of variant $\mathrm{E}$ has not been reported earlier.

By liquid chromatography coupled to electrospray mass spectrometry (LC-ESI/MS), either by analysis of caseinomacropeptide (CMP) released from $\kappa$-CN variants A, B, or E (Jensen et al., 2015; Sunds et al., 2019 ) or the intact $\kappa$-CN molecule (Miranda et al., 2020; Nilsson et al., 2020), isoforms of $\kappa$-CN in milk were investigated. The isoforms identified in these stud- ies covered 1 and $2 \mathrm{P}$ (phosphorylated) molecular forms, in combination with $0-3 \mathrm{G}$ (glycosylated) patterns, even in milk at the individual cow level. Specifically, a few of the individual cow milk samples were found to contain low abundant 0P or even 3P forms (Nilsson et al., 2020), though detailed PTM profiles for each variant were not shown. Therefore, it is now revealed to which extent the 3 different variants $\mathrm{A}, \mathrm{B}$, and $\mathrm{E}$ present with different isoform patterns, in different amounts, or both.

The aim of the present study is therefore to specifically investigate the detailed PTM pattern of $\kappa$-CN variant $\mathrm{E}$ in milk from individual $\kappa-\mathrm{CN} \mathrm{EE}$ cows in comparison with milk from AA and BB cows.

\section{MATERIALS AND METHODS}

Intact proteomic analyses of individual cow milk samples of $\kappa$-CN phenotype EE $(\mathrm{n}=12)$ were obtained from Swedish Red (Nilsson et al., 2020) and investigated by LC-ESI/MS (Poulsen et al., 2016). Deconvoluted MS spectra were used to obtain the information on qualitative and quantitative features. The detailed PTM patterns of the $\kappa-\mathrm{CN}$ EE milk were compared with those of AA $(\mathrm{n}=5)$ and $\mathrm{BB}(\mathrm{n}=4)$ milk from individual Danish Holstein cows (Thesbjerg et al., 2021). The LC-ESI/MS results for mass abundances were analyzed using MassHunter 10 (Agilent; Thesbjerg et al., 2021). In short, MassHunter was used to deconvolute the ion chromatograms obtained from the individual milk samples. The deconvoluted masses were then assigned to a $\kappa-\mathrm{CN}$ specific in-house database, consisting of the $\kappa-\mathrm{CN}$ variants $\mathrm{A}, \mathrm{B}$, and $\mathrm{E}$ with $0-3 \mathrm{P}$ and $0-3 \mathrm{G}$ comprising glycosylation combinations as represented by the 5 different glycan types reported earlier (Saito and Itoh, 1992). To allow for process-induced modifications, the database included the possible loss of up to 3 water molecules, the addition of up to 3 deamidations, and the presence of up to 3 sodium adducts. In total, the database contained 2,700 entries. The relative abundance of each $\kappa-\mathrm{CN}$ isoform was calculated as a fraction of the specific ion intensity assigned to total $\kappa-\mathrm{CN}$ ion intensity in each sample. The glycosylation and phosphorylation degrees were calculated as a fraction of glycosylated or phosphorylated $\kappa$ - $\mathrm{CN}$ ion intensities, respectively, relative to total $\kappa-\mathrm{CN}$ ion intensity, in each sample. Statistical analysis was performed by one-way ANOVA with Duncan's post hoc test using SPSS 25.0 software (IBM Corp.). Significant differences are shown for $P<0.05$.

\section{RESULTS AND DISCUSSION}

Figure 1 shows the detailed PTM pattern identified for $\kappa$-CN E, representing a total of 12 unique masses, 
but potentially representing more isoforms as some of the glycan combinations with $(\mathrm{b}, \mathrm{e})$ and $(\mathrm{c} / \mathrm{d}, \mathrm{c} / \mathrm{d})$ have identical masses. These isoforms have been merged into groups, as shown for $1 \mathrm{P} 3 \mathrm{G}(\mathrm{b}, \mathrm{e}, \mathrm{e}), 1 \mathrm{P} 3 \mathrm{G}(\mathrm{c} / \mathrm{d}, \mathrm{c} / \mathrm{d}$, e), or both. As expected, the most abundant isoform was $1 \mathrm{P} 0 \mathrm{G}[70.0 \pm 4.7 \%$ (SD), relative to total $\kappa-\mathrm{CN}$ ], which had a significantly higher abundance over the other isoforms. This was followed by the $2 \mathrm{P} 0 \mathrm{G}(11.7 \pm$ $3.1 \%)$. The most common glycosylation patterns were 1P $2 \mathrm{G}(\mathrm{e}, \mathrm{e})$ and $1 \mathrm{P} 1 \mathrm{G}(\mathrm{e})$, which had relative abundances of $6.7 \pm 1.5 \%$ and $5.7 \pm 2.1 \%$, respectively. This was followed by $1 \mathrm{P} 3 \mathrm{G}(\mathrm{e}, \mathrm{e}, \mathrm{e})(2.3 \pm 0.7 \%)$. Other low abundant isoforms, including $1 \mathrm{P} 1 \mathrm{G}(\mathrm{c} / \mathrm{d}), 1 \mathrm{P} 2 \mathrm{G}(\mathrm{c} / \mathrm{d}$, e), 1P 3G (b, e, e), 1P 3G (c/d, c/d, e), 1P 3G (c/d, $\mathrm{e}, \mathrm{e}), 2 \mathrm{P} 2 \mathrm{G}(\mathrm{e}, \mathrm{e})$, and $2 \mathrm{P} 3 \mathrm{G}(\mathrm{e}, \mathrm{e}, \mathrm{e})$, all had relative abundances $<1 \%$ of total $\kappa-\mathrm{CN}$. Taken together, the most common glycan was type e, followed by $\mathrm{c} / \mathrm{d}$ and b. No type a glycan was identified for variant E. Furthermore, small amounts of the rare 3P 0G isoform were identified among $\mathrm{E}$ isoforms. All isoforms identified for variant $\mathrm{E}$ were phosphorylated.

Combined results of pure qualitative mass identifications of PTM isoforms of skim milk representing homozygous milk of $\kappa$-CN EE $(\mathrm{n}=12)$, AA $(\mathrm{n}=5)$, and BB $(\mathrm{n}=4)$ cows are shown in Figure 2. In total, 17 unique masses were identified for variant $\mathrm{B}$ and 14 unique masses for variant $\mathrm{A}$. Therefore, variant $\mathrm{B}$ comprised a larger heterogeneity in PTM isoforms than both A and $\mathrm{E}$ (12 unique masses). In total, 10 to 11 PTM isoforms were identified for all protein variants, including $1 \mathrm{P}$ 0G, 1P 1G (e), 1P 2G (c/d, e), 1P 2G (e, e), 1P 3G (b, e, e), 1P 3G (c/d, c/d, e), 1P 3G (c/d, e, e), 1P $3 \mathrm{G}(\mathrm{e}, \mathrm{e}, \mathrm{e}), 2 \mathrm{P} 0 \mathrm{G}, 2 \mathrm{P} 2 \mathrm{G}(\mathrm{e}, \mathrm{e})$, and $2 \mathrm{P} 3 \mathrm{G}(\mathrm{e}, \mathrm{e}, \mathrm{e})$. Remarkable differences include the presence of the rare $3 \mathrm{P}$ 0G isoform in variant $\mathrm{E}$, whereas no $3 \mathrm{P}$ forms were detected in variant $\mathrm{A}$ or $\mathrm{B}$. Additionally, very small amounts of $0 \mathrm{P}$ forms (with either 2 or $3 \mathrm{G}$ ) were found in variants $\mathrm{A}$ and $\mathrm{B}$, but not in variant $\mathrm{E}$ (Figure 2).

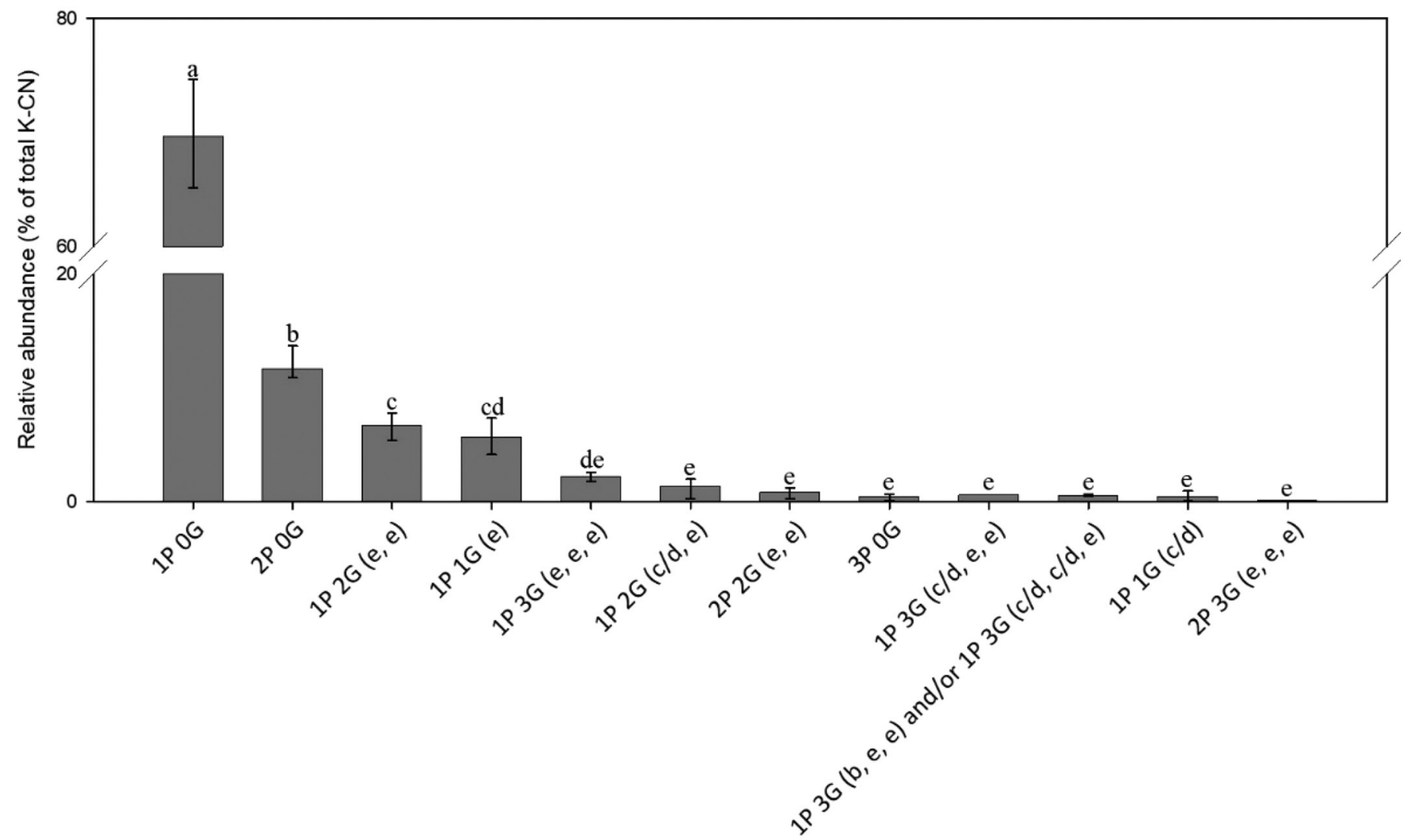

Figure 1. Relative abundance of posttranslational modification isoforms of $\kappa$-CN variant E expressed as their specific ion intensity relative to total $\kappa-\mathrm{CN}$ intensity of the liquid chromatography-electrospray ionization-MS of skim milk samples $(\mathrm{n}=12)$. $\mathrm{P}$ indicates phosphorylation from single to triple phosphorylation (1-3P); G indicates glycosylation from single to triple glycosylation (1-3G). Lowercase letters in parentheses represent the 5 glycan types: (a) $N$-acetylgalactosamine (GalNAc), (b) galactose (Gal) $\beta(1-3)$ GalNAc, (c) $N$-acetyl-neuraminic acid (NeuAc) $\alpha(2-3)$ Gal $\beta(1-3)$ GalNAc, (d) Gal $\beta(1-3)[$ NeuAc $\alpha(2-6)]$ GalNAc, and (e) NeuAc $\alpha(2-3)$ Gal $\beta(1-3)[N e u A c \alpha(2-6)]$ GalNAc. Different lowercase letters $(\mathrm{a}-\mathrm{e})$ above the whiskers represent significant different values within each isoform across phenotypes calculated by one-way ANOVA, $P<$ 0.05. Error bars represent SD. The $2 \mathrm{G}$ forms with (b, e) or (c/d, c/d) had same molecular masses and thus could not be discriminated. 


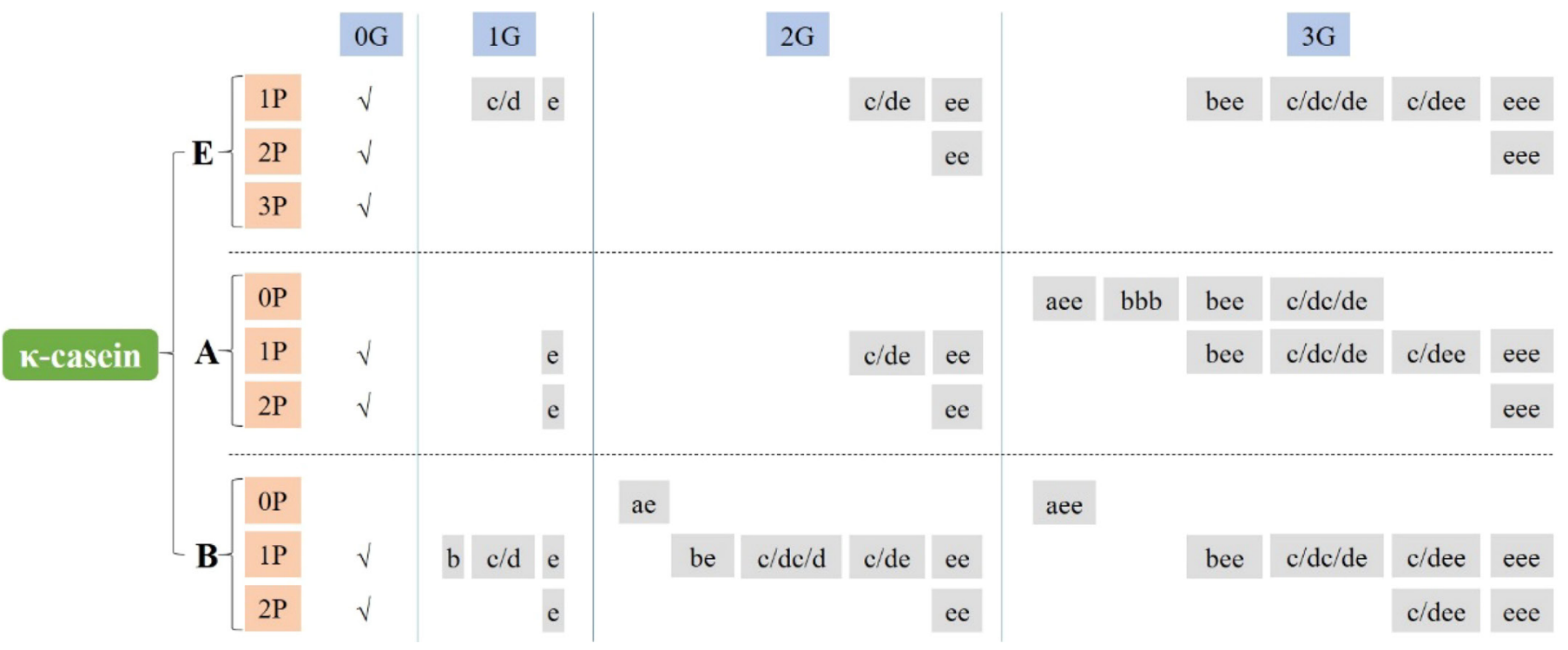

Figure 2. Schematic representation of specific posttranslational modification isoforms identified of $\kappa$-CN variants $\mathrm{E}(\mathrm{n}=12)$, A $(\mathrm{n}=5)$, and $\mathrm{B}(\mathrm{n}=4)$ by liquid chromatography-electrospray ionization-MS of skim milk. P indicates phosphorylation from single to triple phosphorylation (1-3P); G indicates glycosylation from single to triple glycosylation (1-3G). Lowercase letters in gray boxes represent the 5 glycan types, a: $N$-acetylgalactosamine (GalNAc), b: galactose (Gal) $\beta(1-3)$ GalNAc, c: $N$-acetyl-neuraminic acid (NeuAc) $\alpha(2-3)$ Gal $\beta(1-3)$ GalNAc, d: Gal $\beta(1-$ 3) $[\operatorname{NeuAc} \alpha(2-6)]$ GalNAc, and e: NeuAc $\alpha(2-3) \operatorname{Gal} \beta(1-3)[\operatorname{NeuAc} \alpha(2-6)]$ GalNAc.

Apart from the major $1 \mathrm{P} 0 \mathrm{G}$ isoform, $\kappa$-CN normally also has a relatively high abundance of the $2 \mathrm{P} 0 \mathrm{G}$ isoform (Jensen et al., 2015; Sunds et al., 2019; Nilsson et al., 2020), as also observed here for the E variant (Figure 1). The primary sites for phosphorylation are, as mentioned, Ser ${ }^{170}$ and partly Ser ${ }^{148}$. Additionally, a possible third phosphorylation site of $\kappa-\mathrm{CN}$ variants $\mathrm{A}$ and B was reported for Thr ${ }^{166}$ (Holland et al., 2006). This site matches well the general motif Ser/Thr-Xxx-Glu/ Asp/pSer for phosphorylation, though with Ser residues preferred over Thr (Mercier et al., 1973; Kjeldsen et al., 2003; Hernández-Hernández et al., 2011). In addition, Ser ${ }^{187}$ constitutes a potential third phosphorylation site (Hernández-Hernández et al., 2011). Therefore, the third phosphorylation identified here in $\kappa$ - $\mathrm{CN}$ variant E could be at $\mathrm{Thr}^{166}$ or at $\mathrm{Ser}^{187}$. It should be noted that $\mathrm{Thr}^{166}$ can also be O-glycosylated, and therefore may compete with phosphorylation. Type e glycan was the most common glycan form attached in variant $\mathrm{E}$, consistent with earlier observations for variants A and B (Saito and Itoh, 1992; Nilsson et al., 2020).

To compare the most prevalent PTM isoforms present in comparison for all 3 genetic variants, we determined the relative abundances for each major isoform. Figure 3 displays the overall PTM patterns of the 3 genetic variants. Variant $\mathrm{E}$ largely followed the pattern of variants $\mathrm{A}$ and $\mathrm{B}$ in terms of common and rare isoforms, but also some interesting differences could be observed in the relative abundances. Variants E and
B had significantly lower relative abundance of the 1P 0G isoform (around 70\%) compared with variant A (around 80\%). Furthermore, variant E had significantly higher relative abundance of the $1 \mathrm{P} 1 \mathrm{G}$ isoforms com-

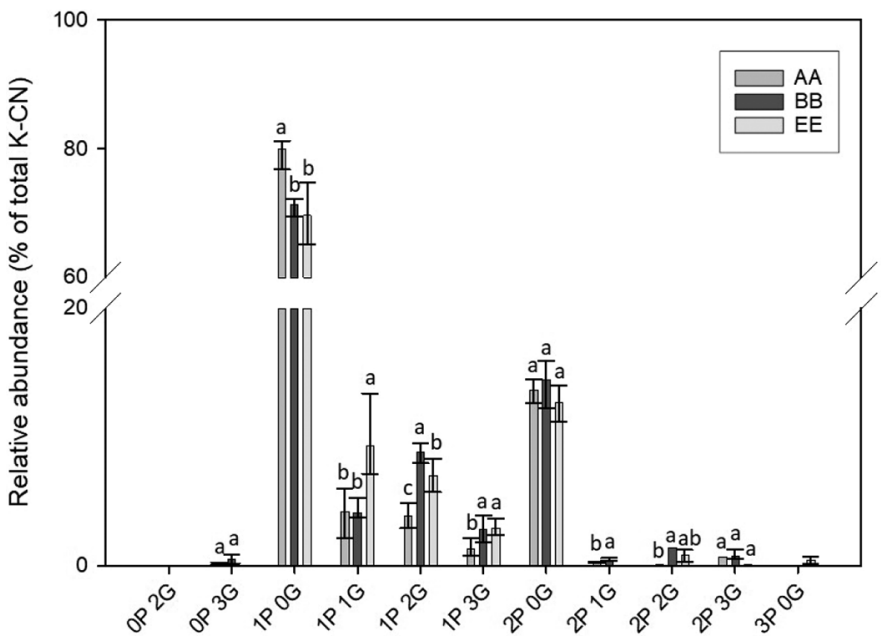

Figure 3. Relative abundances of posttranslational modification groups of $\kappa-\mathrm{CN}$ in milk samples representing genetic variants $\mathrm{A}(\mathrm{n}=$ $5)$, $\mathrm{B}(\mathrm{n}=4)$, and $\mathrm{E}(\mathrm{n}=12)$. The ratio was calculated as specific ion intensity of each isoform relative to total $\kappa-\mathrm{CN}$ ion intensity. $\mathrm{P}$ indicates phosphorylation from single to triple phosphorylation (1$3 \mathrm{P})$, and $\mathrm{G}$ indicates glycosylation from single to triple glycosylation (1-3G). Different lowercase letters $(\mathrm{a}-\mathrm{c})$ above the whiskers represent significant different values within each isoform across phenotypes calculated by one-way ANOVA, $P<0.05$. Error bars represent SD. 
pared with both variants A and B. For $1 \mathrm{P} 2 \mathrm{G}$ isoforms, variant $\mathrm{E}$ had a significantly higher relative abundance than variant $A$, but significantly lower than variant $B$. Variants B and E had similar relative abundance of the 1P 3G isoforms, which was significantly higher than variant $\mathrm{A}$.

Using LC-ESI/MS, Nilsson et al. (2020) identified various PTM isoforms for $\kappa-\mathrm{CN}$ variants $\mathrm{A}, \mathrm{B}$, and $\mathrm{E}$ in Swedish Red dairy cattle. However, Nilsson et al. (2020) did not specify the exact isoforms per variant or their relative abundance. In comparison, the present study identified each specific isoform and its relative abundance for the $\kappa-\mathrm{CN}$ variants $\mathrm{A}, \mathrm{B}$, and E. Additionally, Sunds et al. (2019) identified the 1P 0G, 1P 2G (e, e), and 2P 0G isoforms in a LC-ESI/MS Single Q study of commercial caseinomacropeptide isolates (Lacprodan cGMP-20, Arla Foods Ingredients), cleaved from each of these 3 genetic variants, which were all found in the present study. According to Thesbjerg et al. (2021), the most common glycosylated isoforms of $\kappa-\mathrm{CN} \mathrm{A}$ and $\mathrm{B}$ in Danish Holstein-Friesian cows were the 1P 2G (e, e) followed by $1 \mathrm{P} 1 \mathrm{G}$ (e) and $1 \mathrm{P} 3 \mathrm{G}(\mathrm{e}, \mathrm{e}, \mathrm{e})$.

A limitation of these previous studies (Sunds et al., 2019; Nilsson et al., 2020; Thesbjerg et al., 2021) and the present study is that the intact protein analysis performed using different types of LC-MS methodologies did not provide or report data on the specific modification sites of $\kappa-\mathrm{CN}$, and this could be interesting to investigate for variant $\mathrm{E}$ using a MS/MS-based analysis. The 2 main phosphorylation sites $\left(\operatorname{Ser}^{148}\right.$ and $\operatorname{Ser}^{170}$ ), as well as the 6 shared glycosylation sites $\left(\mathrm{Thr}^{142}\right.$, $\mathrm{Thr}^{152}$, Thr ${ }^{154}$, Thr ${ }^{163}$, $\mathrm{Thr}^{166}$, and $\mathrm{Thr}^{186}$ ) and the additional Thr $^{157}$ for variants A and E. These sites had been confirmed by bottom-up proteomics using tandem MS from enzymatic hydrolysis of $\kappa$-CN separated by 2-dimensional gel electrophoresis (Pisano et al., 1994; Holland et al., 2005, 2006). However, the quantitative PTM patterns of the different genetic variants were not reported.

Taken together, among $\kappa$-CN with different levels of phosphorylation from 0 to $3 \mathrm{P}$, the $1 \mathrm{P} \kappa-\mathrm{CN}$ molecules displayed more diversity of glycosylated isoforms compared with the other phosphorylation isoforms. All $\kappa$-CN variant $\mathrm{E}$ isoforms were found to be phosphorylated, giving a phosphorylation degree of $100 \%$, and the phosphorylation degrees of variants $\mathrm{A}$ and $\mathrm{B}$ were almost $100 \%$. Another important characteristic, the glycosylation degree can be calculated either by the relative peak area based on UV $214 \mathrm{~nm}$ (Poulsen et al., 2016), or by the ion intensity values as in the present study. From the present study, $\kappa-\mathrm{CN}$ variant $\mathrm{E}$ was calculated to have a glycosylation degree of 17.5 $\pm 6.1 \%$, and for $\kappa$-CN variant B of $14.2 \pm 3.6 \%$, both being significantly higher $(P<0.05)$ than that of variant $\mathrm{A}(6.9 \pm 2.5 \%)$. The difference in glycosylation degree between $\mathrm{A}$ and $\mathrm{B}$ is consistent with previous studies based on UV peak areas; for example, Poulsen et al. (2016) found 23 and $28 \%$ for variants A and B in Danish Holstein cows, respectively, and 17 and $21 \%$ for variants A and B in Danish Jersey cows, respectively. The different value between each study might be due to different samples and more importantly methodologies. To the best of our knowledge, neither the phosphorylation nor glycosylation degree of $\kappa-\mathrm{CN}$ variant $\mathrm{E}$ have been reported earlier.

$\kappa$-Casein genetic variants $\mathrm{A}, \mathrm{B}$, and $\mathrm{E}$ showed different PTM with varying levels, which could influence casein micelle size and cause variation in the total concentration of $\kappa-\mathrm{CN}$ in milk (Bijl et al., 2014; Poulsen et al., 2016; Sheng et al., 2021). In combination, these factors could affect the technological properties of milk, for example, rennet-induced coagulation (Jensen et al., 2012) and formation of acid-induced milk gels (Gustavsson et al., 2014; Glantz et al., 2015; Nilsson et al., 2020). In this study, the casein micelle size of EE homozygous milk still remains to be elucidated, whereas Poulsen et al. (2017b) found that the AE haplotype displayed smaller casein micelle size than haplotypes A and B. However, the exact effect of phosphorylation and glycosylation pattern of $\kappa-\mathrm{CN}$ on these technological properties still needs to be investigated, especially in the context of good, poor, and noncoagulating milk. Investigations have pointed out the importance of glycosylation degree for coagulation properties of milk samples, for which coagulation ability increased with a higher fraction of glycosylated $\kappa-\mathrm{CN}$ (Bonfatti et al., 2014; Poulsen et al., 2016), but apparently not of importance in noncoagulating milk (Nilsson et al., 2020). Complying with the observation here of a glycosylation degree of variant $\mathrm{E}$ comparable with variant $\mathrm{B}$, the potential association of variant $\mathrm{E}$ with good coagulation needs further investigation.

Recently, it was shown in an in vitro study that $\kappa-\mathrm{CN}$ AA milk had faster gastric digestion rate than $\mathrm{BB}$ and AB milk (Sheng et al., 2021). Therefore, it is also worth investigating the implications of the variabilities in the PTM modifications of $\kappa$-CN genetic variants that could affect their digestibility and peptide release to ascertain if some isoforms or variants are more digestible than others.

\section{ACKNOWLEDGMENTS}

The authors thank Gitte H. Kristiansen (Department of Food Science, Aarhus University, Denmark) for operating the LC-ESI/MS. We are grateful to the China 
Scholarship Council (Beijing, China) for enabling Bulei Sheng to carry out his PhD studies at Aarhus University, Denmark. The authors have not stated any conflicts of interest.

\section{REFERENCES}

Bijl, E., R. de Vries, H. Van Valenberg, T. Huppertz, and T. Van Hooijdonk. 2014. Factors influencing casein micelle size in milk of individual cows: Genetic variants and glycosylation of $\kappa$-casein. Int. Dairy J. 34:135-141. https://doi.org/10.1016/j.idairyj.2013.08 .001 .

Bijl, E., T. Huppertz, H. van Valenberg, and C. Holt. 2019. A quantitative model of the bovine casein micelle: Ion equilibria and calcium phosphate sequestration by individual caseins in bovine milk. Eur. Biophys. J. 48:45-59. https://doi.org/10.1007/s00249-018-1330-2.

Bonfatti, V., G. Chiarot, and P. Carnier. 2014. Glycosylation of k-casein: Genetic and non-genetic variation and effects on rennet coagulation properties of milk. J. Dairy Sci. 97:1961-1969. https:/ /doi.org/10.3168/jds.2013-7418.

Caroli, A. M., S. Chessa, and G. J. Erhardt. 2009. Invited review: Milk protein polymorphisms in cattle: Effect on animal breeding and human nutrition. J. Dairy Sci. 92:5335-5352. https://doi.org/10 $.3168 /$ jds.2009-2461.

Glantz, M., T. G. Devold, G. E. Vegarud, H. Lindmark Månsson, H. Stålhammar, and M. Paulsson. 2010. Importance of casein micelle size and milk composition for milk gelation. J. Dairy Sci. 93:14441451. https://doi.org/10.3168/jds.2009-2856.

Glantz, M., F. Gustavsson, H. P. Bertelsen, H. Stålhammar, H. Lindmark-Månsson, M. Paulsson, C. Bendixen, and V. R. Gregersen. 2015. Bovine chromosomal regions affecting rheological traits in acid-induced skim milk gels. J. Dairy Sci. 98:1273-1285. https:// doi.org/10.3168/jds.2014-8137.

Gustavsson, F., A. J. Buitenhuis, M. Glantz, H. Stålhammar, H. Lindmark Månsson, N. A. Poulsen, L. B. Larsen, A. Andrén, and M. Paulsson. 2014. Impact of genetic variants of milk proteins on chymosin-induced gelation properties of milk from individual cows of Swedish Red dairy cattle. Int. Dairy J. 39:102-107. https://doi .org/10.1016/j.idairyj.2014.05.007.

Hallén, E. A., T. Allmere, J. Naslund, A. Andren, and A. Lunden. 2007. Effect of genetic polymorphism of milk proteins on rheology of chymosin-induced milk gels. Int. Dairy J. 17:791-799. https:// doi.org/10.1016/j.idairyj.2006.09.011.

Hernández-Hernández, O., R. Lebrón-Aguilar, J. E. Quintanilla-López, M. L. Sanz, and F. J. Moreno. 2011. Detection of two minor phosphorylation sites for bovine $\kappa$-casein macropeptide by reversedphase liquid chromatography-tandem mass spectrometry. J. Agric. Food Chem. 59:10848-10853. https://doi.org/10.1021/jf203089n.

Holland, J. W., H. C. Deeth, and P. F. Alewood. 2005. Analysis of O-glycosylation site occupancy in bovine $\kappa$-casein glycoforms separated by two-dimensional gel electrophoresis. Proteomics 5:9901002. https://doi.org/10.1002/pmic.200401098.

Holland, J. W., H. C. Deeth, and P. F. Alewood. 2006. Resolution and characterisation of multiple isoforms of bovine kappa-casein by 2-DE following a reversible cysteine-tagging enrichment strategy. Proteomics 6:3087-3095. https://doi.org/10.1002/pmic.200500780.

Ikonen, T., K. Ahlfors, R. Kempe, M. Ojala, and O. Ruottinen. 1999. Genetic parameters for the milk coagulation properties and prevalence of noncoagulating milk in Finnish dairy cows. J. Dairy Sci. 82:205-214. https://doi.org/10.3168/jds.S0022-0302(99)75225-2.

Jensen, H. B., K. S. Pedersen, L. B. Johansen, N. A. Poulsen, M. Bakman, D. E. Chatterton, and L. B. Larsen. 2015. Genetic variation and posttranslational modification of bovine $\kappa$-casein: Effects on caseinomacropeptide release during renneting. J. Dairy Sci. 98:747-758. https://doi.org/10.3168/jds.2014-8678.

Jensen, H. B., N. A. Poulsen, K. K. Andersen, M. Hammershøj, H. D. Poulsen, and L. B. Larsen. 2012. Distinct composition of bovine milk from Jersey and Holstein-Friesian cows with good, poor, or non-coagulation properties as reflected in protein genetic variants and isoforms. J. Dairy Sci. 95:6905-6917. https://doi.org/10.3168/ jds.2012-5675.

Kjeldsen, F., K. F. Haselmann, B. A. Budnik, E. S. Sorensen, and R. A. Zubarev. 2003. Complete characterization of posttranslational modification sites in the bovine milk protein PP3 by tandem mass spectrometry with electron capture dissociation as the last stage. Anal. Chem. 75:2355-2361. https://doi.org/10.1021/ac026295b.

Le, T. T., H. C. Deeth, and L. B. Larsen. 2017. Proteomics of major bovine milk proteins: Novel insights. Int. Dairy J. 67:2-15. https:/ /doi.org/10.1016/j.idairyj.2016.11.016.

Lien, S., J. Kantanen, I. Olsaker, L. E. Holm, E. Eythorsdottir, K. Sandberg, B. Dalsgard, and S. Adalsteinsson. 1999. Comparison of milk protein allele frequencies in Nordic cattle breeds. Anim. Genet. 30:85-91. https://doi.org/10.1046/j.1365-2052.1999.00434.x.

Mercier, J. C., G. Brignon, and B. Ribadeau-Dumas. 1973. Primary structure of bovine kappa B casein. Complete sequence. Eur. J. Biochem. 35:222-235. https://doi.org/10.1111/j.1432-1033.1973 .tb02829.x.

Miranda, G., L. Bianchi, Z. Krupova, P. Trossat, and P. Martin. 2020. An improved LC-MS method to profile molecular diversity and quantify the six main bovine milk proteins, including genetic and splicing variants as well as post-translationally modified isoforms. Food Chem. X 5:100080. https://doi.org/10.1016/j.fochx.2020 .100080 .

Nilsson, K., L. Buhelt Johansen, D. J. de Koning, S. I. Duchemin, M. Stenholdt Hansen, H. Stålhammar, H. Lindmark-Månsson, M. Paulsson, W. F. Fikse, and M. Glantz. 2020. Effects of milk proteins and posttranslational modifications on noncoagulating milk from Swedish Red dairy cattle. J. Dairy Sci. 103:6858-6868. https: //doi.org/10.3168/jds.2020-18357.

Pisano, A., N. H. Packer, J. W. Redmond, K. L. Williams, and A. A Gooley. 1994. Characterization of O-linked glycosylation motifs in the glycopeptide domain of bovine kappa-casein. Glycobiology 4:837-844. https://doi.org/10.1093/glycob/4.6.837.

Poulsen, N. A., H. P. Bertelsen, H. B. Jensen, F. Gustavsson, M. Glantz, H. Lindmark Månsson, A. Andrén, M. Paulsson, C. Bendixen, A. J. Buitenhuis, and L. B. Larsen. 2013. The occurrence of noncoagulating milk and the association of bovine milk coagulation properties with genetic variants of the caseins in 3 Scandinavian dairy breeds. J. Dairy Sci. 96:4830-4842. https://doi.org/10 $.3168 /$ jds.2012-6422.

Poulsen, N. A., M. Glantz, A. K. Rosengaard, M. Paulsson, and L. B. Larsen. 2017a. Comparison of milk protein composition and rennet coagulation properties in native Swedish dairy cow breeds and high-yielding Swedish Red cows. J. Dairy Sci. 100:8722-8734. https://doi.org/10.3168/jds.2017-12920.

Poulsen, N. A., V. R. Gregersen, G. M. Maciel, L. B. Madsen, B Buitenhuis, M. S. Hansen, C. Bendixen, and L. B. Larsen. 2017b. Novel genetic variation associated to CSN3 strongly affects rennetinduced milk coagulation. Int. Dairy J. 71:122-130. https://doi .org/10.1016/j.idairyj.2017.03.012.

Poulsen, N. A., H. B. Jensen, and L. B. Larsen. 2016. Factors influencing degree of glycosylation and phosphorylation of caseins in individual cow milk samples. J. Dairy Sci. 99:3325-3333. https:// doi.org/10.3168/jds.2015-10226.

Saito, T., and T. Itoh. 1992. Variations and distributions of O-glycosidically linked sugar chains in bovine $\kappa$-casein. J. Dairy Sci. 75:1768-1774. https://doi.org/10.3168/jds.S0022-0302(92)77936 $-3$.

Sheng, B., S. D. Nielsen, N. A. Poulsen, and L. B. Larsen. 2021. Differential in vitro digestion rates in gastric phase of bovine milk with different $\kappa$-casein phenotypes. J. Dairy Sci. 104:10462-10472. https://doi.org/10.3168/jds.2020-20073.

Sunds, A. V., N. A. Poulsen, and L. B. Larsen. 2019. Application of proteomics for characterization of caseinomacropeptide isoforms before and after desialidation. J. Dairy Sci. 102:8696-8703. https: //doi.org/10.3168/jds.2019-16617. 
Talbot, B., and D. F. Waugh. 1970. Micelle-forming characteristics of monomeric and covalent polymeric kappa caseins. Biochemistry 9:2807-2813. https://doi.org/10.1021/bi00816a009.

Thesbjerg, M. N., M. Johansen, L. B. Larsen, and N. A. Poulsen. 2021. Differences in post-translational modifications of proteins in milk from early and mid-lactation dairy cows using the total ion chromatograms from LC-ESI/MS. Int. Dairy J. https://doi. org/10.1016/j.idairyj.2021.105262.

Wedholm, A., L. B. Larsen, H. Lindmark-Mansson, A. H. Karlsson, and A. Andren. 2006. Effect of protein composition on the cheesemaking properties of milk from individual dairy cows. J. Dairy Sci.
89:3296-3305. https://doi.org/10.3168/jds.S0022-0302(06)72366 -9 .

\section{ORCIDS}

Bulei Sheng @ https://orcid.org/0000-0002-2020-8111

Søren D. Nielsen () https://orcid.org/0000-0002-6990-2200

Nina A. Poulsen @ https://orcid.org/0000-0001-9983-9663

Lotte B. Larsen $\odot$ https://orcid.org/0000-0001-9674-0107 